\title{
Measuring progress on diet-related NCDs: the need to address the causes of the causes
}

\author{
Sharon Friel, Ronald Labonte and David Sanders
}

WHO has developed nine voluntary global monitoring targets and 25 indicators to assess progress in the implementation of national strategies to achieve the global political commitment to reduce the probability of dying from non- communicable diseases (NCDs) for people aged 30-70 years, by 25\% by 2025.1,2 Robert Beaglehole and colleagues (Oct 13, p 1283) 3 argue that it is better to focus on two of the population-wide target: tobacco control and dietary salt reduction, and the treatment target, and that the targets should be reported according to socioeconomic status and gender.

We do not believe that these or most of the WHO monitoring frame- work reach the core of the NCD problem. These targets focus on the individualised causes and could lock interventions within a behavioural risk factor paradigm that has been challenged by evidence on the importance of societal factors. 4

To address diet-related NCDs, interventions (and targets) must "tackle the systemic problems that generate poor nutrition in all its forms" and reflect how "our food systems are making people sick". 5 The accumulating international evidence highlights that there are structural issues that affect the availability, affordability, and acceptability of food, which, along with everyday living conditions, affect what people eat. ${ }^{6-8}$ This is seen through food price speculation, land grabs, and the longer-standing issues of liberalised trade and foreign direct investment.

Despite 2008 being a year of record grain production internationally, the dramatic rise in food prices resulted from deregulation of financial and commodities derivatives markets in the USA in 2000. This sparked a sharp increase in traded volumes on agricultural commodity futures, with index fund speculation increasing by $1900 \%$ between 2003 and March, 2008. 9 Such speculation increased price volatility, affecting the poorest most. Global food prices reached record levels in 2011, with many families coping by eating less and reducing the number and quality of meals per day. ${ }^{10}$

Growing national food insecurity is further witnessed by the rise in the number of developing countries that are now food importers (from 74 in 1995-99 to 89 in 200509), ${ }^{11}$ putting them at risk due to price volatility. ${ }^{12}$ More recently, food insecurity is threatened by the rise in land grabs-long-term lease or sales agreements for agricultural 
land to foreign investors intent on biofuel or food crop production for export markets.13,14 The liberalisation of food trade, the escalation of foreign direct investment by (especially) trans- national food corporations, and the rapid spread of supermarkets, in turn, have resulted in an exponential increase in the availability of cheap, energy-dense, nutrient-poor processed foods, even in rural areas..$^{15}$ Studies have shown a dramatic change in the food environment, with cheap ultraprocessed foods becoming increasingly dominant. ${ }^{16}$

In this global context, a focus on behaviour change without enacting policies to address these structural drivers of the food-related NCD epidemic not only obfuscates the true causes of undernutrition and obesity problems, it also shifts the responsi- bility to individuals, especially the most vulnerable. Quoting Lenin, Richard Horton ${ }^{17}$ identifies the context in which this manifestation of economic globalisation is happening and which those concerned with NCD control need to understand and challenge: "Capitalism has grown into a world system of colonial oppression and of the financial strangulation of the overwhelming majority of the people of the world by a handful of 'advanced' countries." We would add to this: "and by transnational corporations".

We declare that we have no conflicts of interest. 


\section{References}

1. UN General Assembly. Political declaration of the High-level Meeting of the General Assembly on the Prevention and Control of Non-communicable Diseases. New York: United Nations, 2011.

2. WHO. Report of the Formal Meeting of Member States to conclude the work on the comprehensive global monitoring framework, including indicators, and a set of voluntary global targets for the prevention and control of noncommunicable diseases, Nov 5-7, 2012. Geneva: World Health Organization, 2012. http://apps.who.int/gb/NCDs/pdf/A_NCD_2-en.pdf (accessed Dec 18, 2012).

3. Beaglehole R, Bonita R, Horton R, et al. Measuring progress on NCDs: one goal and five targets. Lancet 2012; 380: $1283-85$.

4. Commission on the Social Determinants of Health. Closing the gap in a generation: health equity through action on the social determinants of health. Final report of the Commission on Social Determinants of Health. Geneva: World Health Organisation, 2008. http://www.who.int/social_determinants/thecommission/finalreport/en/index.html (accessed Dec 18, 2012).

5. De Schutter O. Five ways to tackle disastrous diets-UN food expert. http://www.srfood. org/index.php/en/component/content/article/1-latest-news/2054-five-ways-totackle-disastrous-diets-un-food-expert (accesed Dec 18, 2012).

6. Lock K, Stuckler D, Charlesworth K, McKee M. Potential causes and health effects of rising global food prices. BMJ 2009; 339: b2403.

7. Standing Committee on Nutrition. The impact of high food prices on maternal and child nutrition. http://reliefweb.int/report/world/impact-high-food-prices-maternal-andchild- nutrition (accessed Dec 18, 2012).

8. Stuckler D, Nestle M. Big food, food systems, and global health. PLos Med 2012; 9: e1001242.

9. De Schutter O. Food commodities speculation and food price crisis. http://www.srfood.org/index.php/en/component/content/article/894-foodcommodities-speculation-and-food-price-crises (accessed Dec 18, 2012).

10. Save the Children. Costing lives: the devastating impact of rising and volatile food prices. http://www.savethechildren.org.uk/ resources/online-library/costing-livesdevastating-impact-rising-and-volatile-food-prices (accessed Dec 18, 2012).

11. Valdés A, Foster W. Net food-importing developing countries: who they are, and policy options for global price volatility. http://ictsd. org/downloads/2012/o8/net-foodimporting- developing-countries-who-they-are-and-policy-options-for-global-pricevolatility.pdf (accessed Dec 18, 2012).

12. Ng F, Aksoy MA. Who are the net food importing countries? http://www-wds. worldbank.org/external/default/WDSContentServer/IW3P/IB/2008/01/02/000 158349_20080102095804/Rendered/PDF/ wps4457.pdf(accessed Dec 18, 2012).

13. GRAIN. The great food robbery: how corporations control food, grab land and destroy the climate. Kenya: Pambazuka Press, 2012.

14. Zerfu Gurara D, Birhanu D. Large-scale land acquisitions in Africa. Africa Econ Brief 2012; 3: 1-8.

15. D'Haese M, Huylenbroeck GV. The rise of supermarkets and changing expenditure patterns of poor rural households case study in the Transkei area, South Africa. Food Policy 2005; 30: 97-113. 
16. Monteiro CA, Levy RB, Claro RM, de Castro IR, Cannon G. Increasing consumption of ultra-processed foods and likely impact on human health: evidence from Brazil. Public Health Nutr 2011; 14: 5-13.

17. Horton R. Offline: The advantages of universal health. Lancet 2012; 380: 1632. 